\title{
Profil Lipid dan Kejadian Hipertensi pada Pria Perokok Berat
}

\author{
Yonrizal Nurdin ${ }^{\mathrm{a}}$ \\ ${ }^{a}$ Program Studi Ilmu Keperawatan Universitas Andalas \\ Email :yonrizal_nurdin@yahoo.com
}

\begin{abstract}
The cigarette will lead to peripheral vasoconstriction of the blood vessels and vessels in the kidneys, leading to an increase in blood pressure. Smoking a every day will improve the systolic pressure $10-25 \mathrm{mmHg}$ and increased heart rate 5-20 times per minute. Early screening profiles of lipids include: examination of total cholesterol, cholesterol low density lipoprotein (LDL), high-density lipoprotein cholesterol (HDL) and triglycerides are indispensable. This examination is used to find the dyslipidemia is associated with coronary heart disease. This research was conducted in Kelurahan Batang Arau work areas of Pemancungan Health Center, Padang. Design research is descriptive and interpret that attempt to describe the object in accordance with what it is. The population in this research are all male heavy smoker aged above 40 years in Kelurahan Batang Arau, work-areas of Pemancungan Health Center, Padang, as much as 64 people. The conclusions of the research there were $28.1 \%$ value is above normal, $53.1 \%$ had low HDL values, $14.5 \%$ have high LDL values, 25\% have high Triglyceride values and $13.6 \%$ in Hypertensive heavy smoker respondents in Kelurahan Batang Arau Kecamatan Padang Selatan work areas of Pemancungan Health Center 2011. Suggested on the heavy smoker to quit smoking immediately and increase the consumption of fruits and vegetables, so that hypertension and cardiovascular disease can be avoided.
\end{abstract}

Keywords : cigarette, blood pressure, phospholipid

\begin{abstract}
Abstrak : Rokok mengakibatkan vasokonstriksi pembuluh darah perifer dan pembuluh di ginjal sehingga terjadi peningkatan tekanan darah. Merokok sebatang setiap hari akan meningkatkan tekanan sistolik 10-25 mmHg dan menambah detak jantung 5-20 kali per menit. Secara dini pemeriksaan profil lipid meliputi pemeriksaan kolesterol total, kolesterol low density lipoprotein (LDL), kolesterol high density lipoprotein (HDL), trigliserida sangat diperlukan. Pemeriksaan ini digunakan untuk mengetahui adanya dislipidemia yang berhubungan dengan adanya penyakit jantung koroner. Penelitian dilakukan di Kelurahan Batang Arau Wilayah Kerja Puskesma Pemancungan, Kota Padang. Desain Penelitian adalah deskriptif yang berusaha menggambarkan dan menginterpretasi objek sesuai dengan apa adanya. Populasi pada penelitian ini adalah semua laki-laki perokok berat yang berusia diatas 40 tahun di Kelurahan Batang Arau ,Wilayah kerja Puskesmas Pemancungan, Kota Padang sebanyak +64 orang. Kesimpulan dari penelitian adalah terdapat $28,1 \%$ nilai diatas normal, $53,1 \%$ mempunyai nilai HDL yang rendah, 23,4 \% mempunyai nilai LDL yang tinggi, $25 \%$ mempunyai nilai Trigliserida tinggi dan 21,9\% Hipertensi pada Responden Perokok Berat di Kelurahan Batang Arau Kecamatan Padang Selatan wilayah kerja Puskesmas Pemancungan Kota Padang Tahun 2011. Disarankan pada perokok berat agar segera berhenti merokok dan banyak mengkonsukmsi buah dan sayur, sehingga hipertensi dan penyakit kardiovaskuler dapat dihindari.
\end{abstract}

Kata kunci : Rokok, tekanan darah, posfolipid 
Prilaku merokok merupakan prilaku yang merugikan, baik bagi individu yang merokok itu sendiri maupun bagi orangorang disekelilingnya. Dilihat dari sisi ekonomi merokok pada dasarnya adalah "membakar uang". Sementara itu dari sisi kesehatan, pengaruh bahan-bahan kimia yang dikandung rokok seperti nikotin, $\mathrm{CO}$ (karbonmonoksida) dan tar akan memacu kerja dari susunan sistem syaraf pusat dan susunan syaraf simpatis sehingga mengakibatkan tekanan darah meningkat dan detak jantung bertambah cepat penyempitan pembuluh darah, tekanan darah tinggi (Soeharto. 2001).

Hipertensi sering kali disebut sebagai pembunuh gelap (silent killer) karena termasuk yang mematikan tanpa disertai dengan gejala-gejalanya lebih dahulu sebagai peringatan bagi korbannya. Hipertensi adalah faktor risiko utama untuk terjadinya penyakit jantung koroner dan gangguan pembuluh darah otak yang dikenal dengan stroke. Bila tekanan darah semakin tinggi maka harapan hidup semakin turun (Soeharto. 2001).

Menurut WHO batas normal tekanan darah adalah 120-140 $\mathrm{mmHg}$ tekanan sistolik dan $80-90 \mathrm{mmHg}$ tekanan diastolik. Seseorang dinyatakan mengidap hipertensi bila tekanan darahnya > 140/90 mmHg (Lanny Sustrani, 2004). Prevalensi hipertensi di seluruh dunia, diperkirakan sekitar 15-20\%. Hipertensi lebih banyak menyerang pada usia setengah baya pada golongan umur 55-64 tahun. Hipertensi di Asia diperkirakan sudah mencapai 8-18\% pada tahun 1997, hipertensi dijumpai pada 4.400 per 10.000 penduduk. Hasil Survey Kesehatan Rumah Tangga tahun 1995, prevalensi hipertensi di Indonesia cukup tinggi, 83 per 1.000 anggota rumah tangga, pada tahun 2000 sekitar 15-20\% masyarakat Indonesia menderita hipertensi (Departemen Kesehatan RI.2003).

Menurut Arjatmo T, Hendra U.2001 bahwa $50 \%$ orang yang diketahui hipertensi pada negara berkembang hanya $25 \%$ yang mendapat pengobatan, dan $12,5 \%$ yang diobati secara baik. Prevalensi hipertensi di
Indonesia mengalami kenaikan dari tahun 1988-1993. Prevalensi hipertensi pada lakilaki dari $134(13,6 \%)$ naik menjadi 165 $(16,5 \%)$, hipertensi pada perempuan dari 174 (16,0\%) naik menjadi 176 (17,6\%). Penelitian yang membandingkan hipertensi pada wanita dan pria oleh Sugiri di daerah kota Semarang diperoleh prevalensi hipertensi $7,5 \%$ pada pria dan $10,9 \%$ pada wanita, sedangkan di daerah kota Jakarta didapatkan 3 prevalensi hipertensi 14,6\% pada pria dan $13,7 \%$ pada wanita.

Rokok akan mengakibatkan vasokonstriksi pembuluh darah perifer dan pembuluh di ginjal sehingga terjadi peningkatan tekanan darah. Merokok sebatang setiap hari akan meningkatkan tekanan sistolik 10-25 $\mathrm{mmHg}$ dan menambah detak jantung 5-20 kali per menit. Beberapa penelitian dalam lingkup kecil juga menunjukkan bukti bahwa merokok dapat menurunkan kolesterol baik (HDL) dan meningkatkan kolesterol jahat (LDL). Kolesterol adalah lemak berwarna kekuningan mirip lilin yang diproduksi tubuh, terutama di dalam hati. Kolesterol adalah salah satu turunan lemak yang beredar dalam darah. Fungsi kolesterol bagi tubuh adalah untuk membuat hormon seks (penting bagi perkembangan dan fungsi organ seksual), hormon korteks adrenal (penting pada metabolisme dan keseimbangan garam dalam tubuh), vitamin D (untuk menyerap kalsium dalam tubuh), serta sebagai garam empedu (membantu usus menyerap lemak) ( G.Sianturi. 2003).

Secara dini pemeriksaan profil lipid meliputi pemeriksaan kolesterol total, kolesterol low density lipoprotein (LDL), kolesterol high density lipoprotein (HDL), trigliserida sangat diperlukan. Pemeriksaan ini ditujukan untuk mengetahui adanya dislipidemia yang berhubungan dengan adanya resiko penyakit jantung koroner yang gejala awalnya adalah hipertensi. Hipertensi atau penyakit darah tinggi adalah gangguan pada pembuluh darah yang mengakibatkan suplai oksigen dan nutrisi yang dibawa oleh darah terhambat sampai ke jaringan tubuh yang membutuhkannya. 
Hipertensi akan memberi gejala yang berlanjut untuk suatu target organ seperti otak (stroke), pembuluh darah jantung (penyakit jantung koroner), otot jantung (left ventricle hypertrophy) (Bustan: 2000).

Kota Padang adalah salah satu kota yang ada di Sumatera barat. Hipertensi merupakan penyebab kematian no 5 di Kota Padang. Puskesmas Pemancungan adalah salah satu Puskesmas dari 11 Puskesmas yang ada di Kota Padang. Diwilayah ini hampir $30 \%$ lansia menderita hipertensi, terutama pada laki- laki. Keadaan ini kalau tidak segera diatasi akan sangat membahayakan para lansia. Sebab dengan meningkatnya umur, fungsi organpun mulai menurun. Pada survey awal yang peneliti lakukan didapatkan data bahwa sebagian laki - laki penderita hipertensi dulunya adalah seorang perokok. Menurut mereka pada saat itu mereka tidak perenah membayangkan kalau diusia mereka yang sudah lansia akan menderita hipertensi. Mereka juga mengatakan kalau mereka baru tahu dari petugas kesehatan bahwa merokok adalah salah satu penyebab hipertensi. Sebagaian besar dari para lansia yang menderita hipertensi tersebut hanya sebagian kecil saja yang memeriksakan kadar propel lipid untuk deteksi dini penyakit kardiovaskuler.

\section{METODE}

Desain Penelitian adalah deskriptif yang berusaha menggambarkan dan menginterpretasi objek sesuai dengan apa adanya. Populasi pada penelitian ini adalah semua laki-laki perokok berat yang berusia diatas 40 tahun di Kelurahan Batang Arau ,Wilayah kerja Puskesmas Pemancungan, Kota Padang sebanyak +64 orang. pemeriksaan yang dilakukan adalah profil lipid meliputi pemeriksaan kolesterol total, kolesterol low density lipoprotein (LDL), kolesterol high density lipoprotein (HDL), trigliserida sangat diperlukan.

\section{HASIL DAN PEMBAHASAN}

Dari table 1 terlihat bahwa 78, 1\% responden mempunyai tekanan darah normal, hanya 21, $9 \%$ respoden yang hipertensi.

Tabel 1. Distribusi frekuensi responden berdasarkan hasil pemeriksaan Tekanan darah di kelurahan Batang Arau

\begin{tabular}{lcc}
\hline Tekanan Darah & F & \% \\
\hline Hipertensi & 14 & 21,9 \\
Tidak hipertensi & 50 & 78,1 \\
Jumlah & 64 & 100 \\
\hline
\end{tabular}

Dari tabel 2 diketahui bahwa $71 \%$ responden mempunyai nilai kolesterol diatas normal, dan $34 \%$ yang mempunyai nlai HDL dibawah normal normal, 76,6 \% nilai LDL diatas normal dan $25 \%$ mempunyai nilai trigliserida diatas normal

Tabel 2. Distribusi frekuensi responden berdasarkan hasil pemeriksaan profil Lipid di kelurahan Batang Arau

\begin{tabular}{lcc}
\hline \multicolumn{1}{c}{ Profil Lipid } & F & \% \\
& & \\
\hline Total kolesterol & & \\
Normal & 46 & 28,1 \\
Diatas normal & 18 & 71,9 \\
\hline HDL : & & \\
Normal & 30 & 46,9 \\
Dibawah normal & 34 & 53,1 \\
\hline LDL : & & \\
Normal & 49 & 76,6 \\
Diatas normal & 15 & 23,4 \\
\hline Tri Gliserida : & & \\
Normal & 48 & 75 \\
Diatas normal & 16 & 25 \\
\hline
\end{tabular}


Prilaku merokok merupakan prilaku yang merugikan, baik bagi individu yang merokok itu sendiri maupun bagi orangorang disekelilingnya. dari sisi kesehatan, pengaruh bahan-bahan kimia yang dikandung rokok seperti nikotin, CO (karbonmonoksida) dan tar akan memacu kerja dari susunan sistem syaraf pusat dan susunan syaraf simpatis sehingga mengakibatkan tekanan darah meningkat dan detak jantung bertambah cepat ( Soeharto. 2001).

Banyak orang yang sudah paham bahwa merokok dapat menimbulkan dampak serius terhadap kesehatan manusia. Bagi masyarakat awam, merokok sudah jelas bisa merusak paru-paru karena asap yang diisap langsung masuk ke paru-paru. Namun banyak orang yang tidak tahu bahwa rokok ternyata juga bisa meningkatkan kadar kolesterol dalam tuubuh manusia.

Dari hasil penelitian yang telah dilakukan didapatkan bahwa pada orang perokok berat tidak semuanya mengalami tekanan darah yang tinggi dan kadar posfolifid yang kurang baik. Hal ini terbukti dari pemeriksaan tekanan darah responden, dari 64 orang responden yang perokok berat didapat hanya 14 orang $(21,9$ $\%$ ) yang menderita hipertensi. Kemudian dari 64 orang responden yang telah diperiksa kadar posfolipidnya didapat 46,9 $\%$ mempunyai nilai kadar HDL yang normal, kadar LDL diatas normal hanya 23 , $4 \%$, kadar trigliserida yang tinggi hanya 25 $\%$. Keadaan ini tidak sesuai dengan teori yang mengatakan bahwa zat-zat kimia yang terkandung dalam rokok, terutama nikotin, dapat menurunkan kadar kolesterol baik (HDL) dan meningkatkan kadar kolesterol buruk (LDL) dalam darah. Dokter spesialis jantung sekaligus Ketua Perkumpulan Vaskuler Indonesia, Auli Sani mengungkapkan, merokok dapat menyebabkan gangguan metabolisme lemak. Pada orang-orang yang merokok, ditemukan kadar HDL-nya rendah. Itu artinya, pembentukan kolesterol baik, yang bertugas membawa lemak dari jaringan ke hati menjadi terganggu. Sementara kebalikannya justru terjadi pada kadar LDLnya. Pada orang yang merokok ditemukan kadar LDL-nya tinggi, berarti lemak dari hati justru dibawa kembali ke jaringan tubuh.

Dari hasil penelitian yang telah didapat ternyata merokok tidak begitu mempengaruhi kesehatan responden. Hal ini disebabkan karena semua responden adalah orang minang, yang mempunyai kebiasaan mengkonsumsi kelapa dan memakai rempah- rempah yang berfungsi sebagai anti oksidan. Hal ini sesuai dengan hasil penelitian ( Lipoeto.2009) bahwa setiap masakan minang selalu memakai beragam rempah-rempah, antara lain cabai merah, bawang putih, bawang merah, ketumbar, kunyit, lengkuas, serai, jahe, kemiri, daun salam, daun kunyit, daun jeruk. Tujuan utama pemakaian rempah-rempah pada masakan adalah meningkatkan cita rasa yang enak dan gurih, sehingga mampu membangkitkan selera makan, serta menjadi bahan pengawet sebagai antimikroba dan antioksidan.

Selain kadar kolesterol yang tinggi perlu menjadi perhatian kita adalah kadar trigliserida yang tinggi,para peneliti menemukan bahwa kadar trigliserida yang tinggi juga merupakan indikator paling bermakna terjadinya stroke dan penyakit jantung, berapapun kadar kolesterolnya. Kadar trigliserida di atas $200 \mathrm{mg} / \mathrm{dl}$ dianggap tinggi dan menimbulkan resiko serius. Bahkan kadar $150 \mathrm{mg} / \mathrm{dl}$ sampai dengan $199 \mathrm{mg} / \mathrm{dl}$ sudah dianggap batas tinggi.

Menurunkan kadar trigliserida itu sangat penting karena jika kadar trigliserida tinggi beresiko dua sampai tiga kali lebih tinggi menderita penyakit jantung dan stroke meskipun kadar kolesterol totalnya rendah, Untuk diet menurunkan trigliserida mulailah dengan memperbanyak makanan tinggi protein tak berlemak, mengganti karbohidrat yang nilai glikemiknya tinggi dengan karbohidrat berglikemik rendah serta memperbanyak konsumsi buah-buahan dan sayuran segar yang mengandung serat tinggi. Usaha lain yang perlu dilakukan adalah mengganti konsumsi lemak jenuh 
dengan lemak tak jenuh, menurunkan total lemak makanan sampai 20\%-30\% dari kebutuhan energi total dan pertahankan berat badan yang ideal, berolah raga minimal 30 menit per hari serta hentikan kebiasaan merokok dan minum minuman beralkohol.

\section{KESIMPULAN DAN SARAN}

Dari penelitian yang telah dilakukan, terdapat $71,9 \%$ nilai total kolesterol tinggi, $53,1 \%$ mempunyai nilai HDL yang rendah, 23,4 \% mempunyai nilai LDL yang tinggi dan $25 \%$ mempunyai nilai trigliserida tinggi , serta terdapat 21,9\% perokok berat di Kelurahan Batang Arau Kecamatan Padang Selatan wilayah kerja Puskesmas Pemancungan Kota Padang Tahun 2011.

Untuk menghindari resiko hipertensi dan penyakit kardiovaskuler perlu segera dilakukan prilaku hidup bersih dan sehat dengan cara berhenti merokok, banyak mengkonsukmsi buah dan sayur, olah raga serta menghindari makanan tinggi lemak.

\section{DAFTAR PUSTAKA}

Arjatmo T, Hendra U.2001. Ilmu Penyakit Dalam. Balai Penerbit FKUI

Bustan, M.N. 2000. Epidemiologi Penyakit Tidak Menular. Rineka Cipta: Jakarta

Departemen Kesehatan RI.2003. Warta Kesehatan Masyarakat. Jakarta: Direktorat Jendral Bina

Iman Soeharto. 2001. Kolesterol Dan Lemak Jahat, Kolesterol Dan Lemak Baik,

Lanny Sustrani, dkk. 2004. Hipertensi. Jakarta. PT. Gramedia Pustaka Utama

G.Sianturi, 2003. Merokok Dan Kesehatan. . http.//kompas.com

NI Lipoeto, DP Putra, Helmizar, Susmiati, Yondrizal; Consumption of spices and antioxidant activities of minangkabau traditional food; Symposium on Polyphenol: Nutrition, Innovetion and Health; Kuala Lumpur, 22-23 June, 2009 